\title{
Mirosław Szegda
}

Nowe spojrzenie na

katolicko-prawosławny rozłam

Prawo Kanoniczne : kwartalnik prawno-historyczny 5/3-4, 233-242

1962

Artykuł został zdigitalizowany i opracowany do udostępnienia w internecie przez Muzeum Historii Polski w ramach prac podejmowanych na rzecz zapewnienia otwartego, powszechnego i trwałego dostępu do polskiego dorobku naukowego i kulturalnego. Artykuł jest umieszczony w kolekcji cyfrowej bazhum.muzhp.pl, gromadzącej zawartość polskich czasopism humanistycznych i społecznych.

Tekst jest udostępniony do wykorzystania w ramach dozwolonego użytku. 


\section{NOWE SPOJRZENIE NA KATOLICKO-PRAWOSEAWNY ROZEAM}

Przeniesienie stolicy cesarstwa rzymskiego z Rzymu do Konstantynopola (330), a następnie podział tegoż cesarstwa na wschodnie i zachodnie (395), doprowadziły do terytorialnego podziału chrześcijaństwa oraz do rywalizacji Konstantynopola $z$ Rzymem. Biskup Konstantynopola bowiem walczył o zrównanie go $z$ papieżem $w$ dziedzinie religijnej, kiedy poczuł się już równym papieżowi pod względem politycznym. Mimo to do drugiej polowy XI wieku chrześcijanie żyli zasadniczo $\mathrm{w}$ jedności, gdyz herezje takie, jak arianizm, nestorianizm czy monofizytyzm po przejściowych powodzeniach traciły na sile i znaczeniu, a zatarg z Focjuszem był również tylko przejściowy. Dopiero patriarcha Cerulariusz, który usilował nawet cesarza usunąć z tronu, by stać się samowładcą chrześcijańskiego Wschodu, zerwał z Kościołem Rzymskim i zapanował nad całym Kościołem Wschodnim. Ten pierwszy wielki rozłam w Kościele Chrystusowym stał się największym niepowodzeniem chrześcijaństwa $\mathrm{w}$ historii i przetrwał aż do naszych czasów.

Niemniej jednak tęsknota za utraconą jednością przez wszystkie wieki pobudzała chrześcijan do coraz to nowych prób pojednania, dziś zaś szczególnie przybrała na sile. Dziś bowiem chrześcijanie wszystkich wyznań zrozumieli, iż ich rozłam jest grzechem, gdyż sprzeciwia się wyraźnej woli Chrystusa Pana. Uświadomili sobie winę i odpowiedzialność za pożałowania godny stan rozdartego i skłóconego świata chrześcijańskiego. Wreszcie sama atmosfera niepokoju, grozy i lęku przed samobójstwem oraz zagładą ludzkości, nakazuje 
chrześcijanom jednoczyć się, aby miłość zwyciężyła nienawiść, a pokój wojnę.

Dziś więc $\mathrm{W}$ czasie wzmożonego ekumenizmu $\mathrm{z}$ całą ostrością staje przed nami pytanie: Jak pojednać Kościoły Wschodni z Zachodnim? Czy tak, jak tego sobie życzy Kościół Katolicki, czy zaś jak Kościół Prawosławny? Otóż zdariem teologów ekumenicznych obydwa Kościoły winny raczej się starać szczególnie o to, aby różnice między nimi stopniowo się zmniejszały, a wreszcie z czasem znikły zupełnie. A zmaleje przedział dzielący obydwa Kościoły, jeśli dojdzie chociaż do obiektywnej analizy samego aktu podziału Kościoła Chrystusowego za Cerulariusza oraz zidentyfikowania właściwych przyczyn tego bolesnego dramatu. Byłoby to zresztą zgodne z tezą Włodzimierza Sołowiewa, ojca katolicyzmu rosyjskiego, który stale dowodził, iz $w$ pracy nad zjednoczeniem Wschodu z. Zachodem należy wszystkie pytania sporne między oboma Kościołami ciągle badać na nowo, nie dla celów jednak polemicznych, ale z pragnieniem wzajemnego porozumienia. Spróbujmy więc obecnie zestawić fakty.

Przez pierwsze cztery i pół wieku jedynie biskupstwa Rzymu, Antiochii i Aleksandrii cieszyły się przywilejem patriarchatów ${ }^{1}$, a to ze względu na starożytność i świetność tych Kościołów oraz wyjątkową godność św. Piotra Ap., który osobiście założył biskupstwo w Antiochii i Rzymie, a przez św. Marka Ewangelistę w Aleksandrii. Konstantynopol zaś $\mathrm{w}$ tym czasie tworzył jedynie małe biskupstwo, zależne od metropolity Heraklei. Dopiero po przeniesieniu przez Konstantyna .W. stolicy cesarstwa do Konstantynopola, zaczyna wzrastać znaczenie tego biskupstwa. Prawosławny teolog prof. Kartaszew (+ 1960) tak scharakteryzował ówczesnego biskupa konstantynopolitańskiego: „Konstantynopol i jego maleńki biskup z maleńką diecezją $w$ granicach jednej stolicy był formalnie zależnym od maleńkiego metropolity Heraklei. Nie posiadał żad-

1 Sobór Niciejski 325 r., kan. 6. 
nej kościelnej przeszłości, żadnych zasług wobec Kościoła i prawosławia. Miał jedynie urojone pretensje, by być jakąś rieproszoną głową Kościoła, narzędziem państwowej władzy. Cała plejada kleryków i zakonników, którzy byli niezadowoleni z sądów swoich biskupów, zjeżdżała do stolicy i apelowała do pałacu (imperatora) za pośrednictyem stołecznego biskupa. I tak znaczenie biskupa bez wszelkich prawdziwie kościelnych podstaw automatycznie urosło ponad cały Kościół, jako nieunikniony skutek upaństwowienia Kościoła ${ }^{2}$. Najpierw więc z podanych przez prof. Kartaszewa powodów podniesiono Konstantynopol do rangi arcybiskupstwa, które następnie w oparciu o władzę świecką zaczęło poszerzać swoje administracyjne wpływy na sąsiednie diecezje. Prof. Kartaszew tak to opisuje: „Nie tylko poniżono metropolię Heraklei, ale nawet całe diecezje zupełnie znikły, Tracja, Bitynia, Pont, Azja wpadiy $w$ orbite jego wpływów i utworzyły terytorium patriarchatu. Takie automatyczne zawojowanie, taki kościelny imperializm konstantynopolitańskiego biskupa - nie mógł nie wzbudzić sprzeciwu ze strony wchłoniętych, obrażonych i tak przez niego złupionych. Mimo to z pomocą Teodozjusza W. na Soborze Konstantynopolitańskim (381) stolicę, która jeszcze nie oczyściła się z brudu arianizmu, ogłoszono pod względem kościelnym jako drugą według czci i praw po starożytnym Rzymie. Czego Rzym nigdy nie przyznał, a dla Aleksandrii było to uderzenie nożem w serce" ${ }^{3}$.

Co więcej na Soborze w Chalcedonie (451) przyznano arcybiskupom Konstantynopola tytuł patriarchy $z$ uwagi na to, iż mieli siedzibe $w$ stolicy cesarstwa rzymskiego. A kiedy juz biskup Konstantynopola został wyniesiony do godności patriarchy, zaczął otwarcie rywalizować z dawnymi patriarchami oraz uszczuplać ich prawa i przywileje. Patriarcha konstantynopolitański zapragnął bowiem stać się zwierzchnikiem całego chrześcijańskiego Wschodu. Dążenie to datuje się głów-

${ }^{2}$ K artašev A. V., $\mathrm{Na}$ putjach k'vselenskomu soboru, Paris $1932,31$.

${ }^{3} \mathrm{~K}$ arta šev A. V., j. w., 31 . 
nie od szóstego wieku, kiedy to w 518 roku patriarcha konstantynopolitański, mimo sprzeciwu papieża, przybrał tytuł „patriarchy ekumenicznego". Rzym zaś broniąc patriarchów i biskupów wschodnich przed hegemonią Konstantynopola, sprzeciwiał się wywyższeniu patriarchy, uważał bowiem za niebezpieczne dla wiary na Wschodzie to wyniesienie patriarchy, gdyż jak dotąd właśnie sami patriarchowie konstantynopolitańscy często byli twórcami lub zwolennikami różnych herezji. Do Focjusza historia zanotowała przynajmniej siedem schizm przejściowych, wskutek czego aż 219 lat Kościół Wschodni by $¥$ pozbawiony jedności z Rzymem ${ }^{4}$. Ponadto papieże uważali, iż przyznanie patriarsze zwierzchnictwa nad Wschodem, mogłoby poderwać ideę prymatu biskupa rzymskiego nad całym Kościołem Powszechnym. Patriarchowie konstantynopolitańscy bowiem pragnęli dla swej stolicy prymatu nad innymi patriarchami wschodnimi i niejako delegacji papieskiej na cały Wschód.

Stanowisko Rzymu było słuszne. Nawet ówcześni teologowie wschodni, przeciwni rozłamowi w Kościele, jawnie obwiniali patriarchów konstantynopolitańich o zamach na przywileje biskupa Rzymu 5. Również w nowszych czasach trzeźwo myślący pisarze prawosławni raczej potępiali w tej sprawie Konstantynopol, a nie Rzym. Na przykład wybitny historyk grecki Dimitrakopul całą winę za rozłam składał na patriarchę Cerulariusza ${ }^{6}$. Podobnie głośny kanonista rosyjski prof. Suwurow oskarża Cerulariusza, iż dążąc do uznania go za głowę Kościoła Wschodniego, stał się głównym sprawcą ostatniego rozłamu ${ }^{7}$. Kanoniści rosyjscy tej miary, co Ostroumow, Bierdnikow, jak i wspomniany Suworow, pisząc o początkach hierarchii kościelnej, przychylają się raczej do doktryny katolickiej, iż ustrój Kościoła z Bożego ustanowienia ma być hierarchiczny, a jeden z biskupów ma przewodzić całemu Kościolowi na ziemi. Zresztą sam Cerulariusz pisał do papieża Leona

\footnotetext{
4 I š čak A., Dohmatyka nezjedynenoho Schodu, Lviv 1936, 30.

5 MPG 149, 684-685.

- Historia ton schismatos, 1867, 27.

7 Suvorov N., Vizantijskij Papa, Moskva 1902, 71-78.
} 
IX, iż byłby gotów żyć w zgodzie i jedności z Rzymem, gdyby papież zdecydował się respektować władzę i prawa patriarchów konstantynopolitańskich nad całym chrześcijańskim Wschodem. Wreszcie jest faktem historycznym, iż Grecy najpierw w dwudziestych latach XI wieku próbowali przy pomocy układów uzyskać od Rzymu uznanie patriarchy konstantynopolitańskiego za ,papieża" Wschodu. Gdy się to zaś im nie powiodło i nie mieli nadziei na pokojowe załatwienie tej sprawy, wtedy Cerulariusz postanowił stać się niezależnym zwierzchnikiem całego Kościoła Wschodniego właśnie przez oderwanie go od Rzymu ${ }^{8}$. Oto jaka była główna i bezpośrednia przyczyna podziału Kościoła w XI wieku. A że Cerulariusz był zdolny do zamachu na jedność Kościoła, byle zaspokoić żądzę władzy, świadczy o tym najlepiej historia Grecji, która obwinia go o rywalizację z samym cesarzem o władzę cesarską. Cerulariusz bowiem po zerwaniu z Rzymem zaczął podstępnie spychać casarza $z$ tronu, gdyż sam pragnął pozostać jedynym władcą kościelnym i świeckim na Wschodzie. Żądał, aby cesarz spełniał jego wszystkie życzenia, a gdy Izaak Komnen odmawiał mu czego, groził mu utratą tronu, mówiąc: „Ja ciebie wyniosłem, ja ciebie i zniszczę!" Za te intrygi cesarz złożył Cerulariusza $z$ urzędu patriarchy i skazał na wygnanie ${ }^{9}$.

Rzeczą wielkiej wagi jest to, iż dogmatyczna strona papiestwa oraz prymatu nie była kwestionowana w sporze Konstantynopola z Rzymem. Cerulariusz w ogóle nie występował przeciwko prymatowi papieża ani w pismach przeciwko lacinnikom, ani później $\mathrm{w}$ sporze $\mathrm{z}$ legatami papieskimi ${ }^{10}$. Dopiero po rozłamie kanoniści greccy na podstawie kanonu trzeciego Soboru Konstantynopolitańskiego (381) stworzyli teorię o prawnym przeniesieniu. przywilejów biskupa rzymskiego na patriarchę konstantynopolitańskiego. Przy czym ową uchwałę soborową, że patriarcha konstantynopolitański ma zajmować pierwsze miejsce po biskupie rzymkim, zaczęli tłumaczyć

8 Suvorov N., j. w. 78 .

' Dobrotvorskij I. M., Borba i razdilenie Cerkvej $v$ pol. XI v., w „Chrestjańskoje Ctenie” 1868, t. III, 898-899.

$10 \mathrm{~S}$ a b ol S., Katolictvo i pravoslavije, New York 1955, 294-296. 
w sensie następstwa czasowego. To znaczy, że patriarcha konstantynopolitański zajmuje na Wschodzie nie drugie miejsce po biskupie rzymskim, lecz pierwsze, tylko że później je objął niż biskup rzymski. $Z$ powyższego wynika jasno, iż $w$ sporze chodziło o przywileje czci i władzy dla patriarchy konstantynopolitańskiego nie jako jednak rywala papieża, ale jako jego równoważnika na Wschodzie. Nawet więc gdyby papież uznał patriarchę za swego namiestnika na Wschodzie, to sam nadal pozostałby następcą i spadkobiercą św. Piotra, najwyższą instancją $w$ sprawach wiary i moralności, zwierzchnikiem samego patriarchy konstantynopolitańskiego. Podobnie wnikliwa analiza kanonu 28 Soboru Chalcedońskiego (451) wykazuje, iż również i tam chodziło nie o prymat papieski dla Konstantynopola, lecz o pierwszeństwo wśród stolic biskupich na Wschodzie. Konstantynopol żądal uznania jego pierwszeństwa jako stolicy cesarstwa nad innymi biskupami wschodnimi oraz jakby delegacji papieskiej na Wschód. A dopiero w XVI wieku pod wpływem protestanckich poglądów na ustrój Kościoła idea zwierzchności kościelnej jednego biskupa jako niewygodna, została u prawosławnych zastąpiona teorią równoprawności wszystkich biskupów poszczególnych Kościołów ${ }^{11}$.

Tak dokonał się katolicko-prawosławny rozłam na Wschodzie. Niestety, liczni autorzy prawosławni jeszcze dziś zwykli podawać jako przyczynę rozłamu ,domatyczno-kanoniczne odchylenia Kościoła Zachodniego od wiary Kościoła Powszechnego". Otóż niewątpliwie różnice obrzędowo-dyscyplinarne pomiędzy chrześcijańskim Wschodem i Zachodem istniały, a demagogiczne niekiedy wysuwanie ich nieżyczliwie nastrajało Wschód przeciwko Zachodowi. A z nich jedyną pozornie dogmatyczną różnicą było odmienne określanie tej samej nauki Kościoła o pochodzeniu Ducha Świętego. Na Zachodzie bowiem cd piątego wieku istniała odmienna formuła o pochodzeniu Ducha Swiętego, która prościej i jaśniej oddawała tę samą

11 Za zjednannja sv. Bożych Cerkov, Kremjanec 1933, 12. 
prawdę, a której wcześniej niż Zachód używali na Wschodzie tacy wybitni Ojcowie Kościoła, jak Atanazy, Bazyli, Cyryl Jerozolimski oraz Jan Damasceński. Zresztą Wschód wiedział c istnieniu powyższej różnicy na Zachodzie, a jednak ani Ojcowie wschodni, ani żaden Sobór nie zakwestionowali jej. A wkrótce po rozłamie arcybiskup Tessalonik, Nikita z Marony, wyjaśnił Grekom na podstawie pism Ojców Kościoła, iż nauka rzymska o pochodzeniu Ducha S̃więtego ,od Ojca i Syna” jest ta sama, co i grecka „od Ojca przez Syna” ${ }^{12}$.

Prawie do końca siódmego wieku Grecy nie zwracali w ogóle uwagi na obrzędowe czy dyscyplinarne różnice w Kościele Zachodnim. Dopiero synod trullański (692) zwołany przez cesarza Justyniana II $\mathrm{z}$ udziałem uległych mu biskupów, potępił odmienne zwyczaje i praktyki zachodnie. Ale i to nie pogorszyło stosunków między Wschodem i Zachodem, na odmienne praktyki zachodnie patrzono bowiem jak na normalne zjawisko w rozwoju poszczególnych Kościołów. Sam Focjusz w swych pismach tłumaczył, że: „Różnice w obrzędach, modlitwach, postach lub karności kościelnej nie sprzeciwiają się jedności w wierze" ${ }^{13}$. Zaś biskupi zebrani na IV Konstantynopolitańskim Soborze (869) tłumaczyli te różnice słowami: „W każdym Kościele są miejscowe zwyczaje, pozostałe $\mathrm{z}$ dawnych czasów - widzimy je w Kościele Rzymskim, Bizantyńskim jak i w innych patriarchatach wschodnich" ${ }^{14}$. Wspomniany natomiast już kanonista Suwurow po zbadaniu źródeł stwierdził autorytatywnie, iż „Wszystkie odmienności zachodnie powstały daleko przed XI wiekiem... A przy każdorazowym polepszeniu stosunków między Rzymem i Konstantynopolem zapominano o ,herezjach" i odnawiano ogólną jedność między Wschodem i Zachodem... Gdy po śmierci Ignacego papież uważał za możliwe zgodzić się na uznanie Focjusza patriarchą... to i sam Focjusz zapominał o swoich oskarżeniach,

12 Por. MPG 139, 169-222.

13 S a bol S., j. w., 293.

${ }^{14}$ Ilarijon Mytrop., Podil jedynoji Chrystovoji Cerkvy i perši sproby pojednannja jiji, Vinnipeg 1952, 213-214. 
wysuniętych przeciwko Zachodowi" ${ }^{15}$ Prawdopodobnie identycznie postąpiłby i Cerulariusz, gdyby papież zgodził się na jego zwierzchnią władzę nad całym Kościołem Wschodnim.

Nic więc dziwnego, że współczesny nam profesor prawa kościelnego $\mathrm{w}$ Atenach, $\mathrm{H}$. Aliwizatos, wysuną koncepcje pojednania obydwu Kościołów na gruncie nauki i dyscypliny, zawierających właśnie te wszystkie różnice z czasów rozłamu katolicko-prawosławnego. Według niego bowiem dzisiejsze różnice (oprócz dogmatów ogłoszonych przez Kościół Katolicki już po rozłamie) między oboma Kościołami nie powstały po rozłamie, ale istniały już daleko wcześniej, a jednak obydwa Kościoły, aby nie zrywać jedności kościelnej, żyły w atmosferze pokojowej koegzystencji. Kościół Wschodni nie kwestionowal wzrostu autorytetu papieskiego na Zachodzie, a papież nie mieszał się do wewnętrznych spraw Wschodu. Ostatecznie prof. Aliwizatos dochodzi do wniosku, iż do rozłamu doprowadziły względy ambicjonalne ${ }^{16}$. A więc $i$ tu mamy potwierdzenie tezy, że rywalizacja i walka o władzę spowodowały podział Kościoła.

Pozostaje jeszcze do wyświetlenia sprawa ekskomuniki, rzuconej przez legatów papieskich na patriarchę Cerulariusza. Niektórzy bowiem autorzy prawosławni przypisują wymienioną ekskomunikę papieżowi, a ogłoszenie jej uważają za akt schizmy Kościoła Rzymskiego. Po prostu twierdzą oni bezpodstawnie, że to właśnie Rzym wraz z całym Kościołem Zachodnim przez rzucenie ekskomuniki na Kościół Wschodni dopuścił się schizmy i oderwał się od Kościoła Powszechnego. Według nich więc nie Kościół Wschodni, ale Kościół Katolicki jest schizmatyckim i pozostaje od XI wieku w odszczepieństwie.

Otóż, chociaż legaci papiescy, grzesząc nierozwagą oraz brakiem cierpliwości i dyplomacji, przyśpieszyli i pogłębili rozłam przez pochopne użycie ekskomuniki, to jednak ekskomuniko-

is Suvorov N., Učebnik cerkovnago prava. Moskwa 1912, 63.

16 Alivisatos H., The proposed Ecumenical Council and Reunion, w „Ecumenical Review”, 1959, I, 22. 
wali oni jedynie Cerulariusza i jego zwolenników, nie zaś Kościół Grecki czy też w ogóle Kościół Wschodni ${ }^{17}$. Ze źródeł bowiem wyraźnie wynika, iż legaci przy ogłaszaniu ekskomuniki na Cerulariusza chwalili cesarza, kler oraz lud grecki za ich przykładną pobożność. Wskutek czego też Cerulariusz w edykcie synodalnym rzucił klątwę nie na papieża, ani na Kościół Rzymski, a jedynie na legatów i tych, którzy brali udział w przygotowaniu bulli ekskomunikującej. A więc nie Kościół wyklinał Kościół, ale wyklinali siebie wzajemnie skłóceni dostojnicy kościelni. Dodajmy, że ekskomunika legatów papieskich nie posiadała $\mathrm{w}$ ogóle żadnego znaczenia kanonicznego, gdyż ani sam papież nie nałożył tej ekskomuniki, ani też nie upoważnił do tego swoich legatów. Dlatego to żaden z ówczesnych historyków greckich nawet nie wspomniał o tej ekskomunice. Niesłusznie więc uważamy datę ogłoszenia ekskomuniki przez kardynała Humberta na Cerulariusza za datę powstania rozłamu w Kościele, chociaż prawdą jest, iz cdtąd jedność kościelna została poważnie zachwiana i w krótkim już czasie (ok. 1075) Kościół Wschodni oderwał się całkowicie od Kościoła Powszechnego.

Przez pseudoekskomunikę więc Rzym ani nie wyklął Koscioła Wschodniego, ani kanonicznie nie zerwał jedności z nim. Jeśli zaś chodzi o schizmę, to wiemy, iż powstaje ona przez separację od prawowitej władzy kościelnej. A jest faktem bezspornym, iż patriarcha konstantynopolitański w tym czasie nie posiadał, ani nawet nie uzurpowal sobie zwierzchnictwa nad Kościołem Rzymskim czy też Zachodnim. A więc i Kościół Rzymski nie mógł się oderwać przez schizmę od Kościoła Greckiego.

Na zakończenie należy zaznaczyć, że chociaż Cerulariusz ze względów ambicjonalnych dokonał podziału Kościoła Powszechnego, to jednak było by błędem całą winę za to składać na jednego człowieka. Przedstawiony $w$ tym artykule rozłam był bowiem tylko następstwem pogłębiającego się już od wie-

17 NPL 143, 1003-1004.

16 -. Prawo Kanoniczne Nir 3-4 
ków rozdźwięku między Wschodem i Zachodem. Grunt pod rozłam przygotowały takie czynniki, jak: odmienny charakter oraz kultura narodów Wschodu i Zachodu, narodowy i polityczny antagonizm, obrzędowo-dyscyplinarne różnice i niecierpliwość Greków odnośnie tychże różnic. Chociaż również prawdą jest, iż niekiedy Kościół Rzymski oraz jego przedstawiciele zapominali, iż przewodnictwo należy pełnić $w$ miłości. Grecy bowiem szczycili się stale swoją kulturą antyczną, sztuką i filozofią. Od czasu zaś przeniesienia stolicy imperium z. Rzymu do Konstantynopola, uważali się za spodkobierców również i kultury rzymskiej, wskutek czego niechętnie tylko patrzyli na zwierzchnictwo biskupa Rzymu nad Wschodem.

Dziś prawie wszystkie te przyczyny, dla których doszło do rozłamu, należą już do historii. Ale, niestety, w ciągu następnych stuleci na ich miejsce wyrosła na drodze do pojednania góra uprzedzeń, wzajemnych niechęci i podejrzeń. I dziś należy niestrudzenie pracować właśnie nad usunięciem tej chyba największej przeszkody i utorowaniem drogi do pojednania między Kościołem Wschodnim i Zachodnim. Należy wysuwać to, co nas wzajemnie łączy ze Wschodem, a różnice wyjaśniać w miłości, zgodnie $z$ hasłem: „Per caritatem ad veritatem Przez miłość do prawdy!" Bo chociaż jesteśmy skłóconymi braćmi, to mimo wszystko nie przestaliśmy być jednak braćmi. Miejmy nadzieję, że Duch Swięty, Duch Prawdy i Matka Boża, która jest tak gorąco szczona na Wschodzie i Zachodzie, pojednają skłóconych braci. Pocieszającym objawem jest to, że nasi bracia niezjednoczeni na wszechprawosławnej Konferencji na Rodos w r. 1961 postanowili nawiązać przyjazne stosunki z Kościołem Rzymskim i zbadać istniejące różnice między Kościołem Katolickim i Prawosławnym.

$\mathrm{XI} / 1962$ 